\title{
Esmolol 光学異性体の体内動態の比較
}

\section{岡村美弥子, 熊谷 正道, 村崎 祐子, 王鞍 孝子, 宮本 好明 河井祥一郎, 田村隆, 高力 豊*, 富澤 宏樹* \\ Stereoselective Pharmacokinetics of Esmolol Enantiomers}

\author{
Miyako Okamura, Masamichi Kumagai, Yuko Murasaki, Takako Ohkura, Yoshiaki Mryamoto, \\ Yoichiro KaWAI, Takashi TAMURA, Yutaka TAKARIKI* and Hiroki TomisaWA* \\ Central Research Laboratory, Maruishi Pharamaceutical Co., Ltd., Osaka \\ *Drug Metabolism and Pharmacokinetics Group, Tsukuba Laboratories, Nemoto Science Co., Ltd., Ibaraki
}

Summary: Esmolol, an ultra-short-acting beta-adrenergic blocker, is a racemate. In this study, to compare the stereoselective pharmacokinetics of enantiomers, we have investigated the blood level profile after a single intravenous administration $(10 \mathrm{mg} / \mathrm{kg})$ of ${ }^{14} \mathrm{C}$-esmolol hydrochloride $\left({ }^{14} \mathrm{C}\right.$-esmolol $)$ to dogs. The distribution into the heart, a target organ, was tested after a single intravenous administration $(20 \mathrm{mg} / \mathrm{kg})$ of ${ }^{14} \mathrm{C}-$ esmolol to rats. Each enantiomer was tested for metabolic conversion by blood esterase (in vitro), and the protein binding. In addition, the chiral inversion was investigated using human (in vitro) and dog blood (in vitro and in vivo).

1. The blood concentration and the AUC of $d$-esmolol were 1.6-fold higher than those of $l$-esmolol, and the half-life of $d$-esmolol was 1.7 -fold longer than that of $l$-esmolol after administration of ${ }^{14} \mathrm{C}$-esmolol to dogs.

2. The half-life of $d$-esmolol was 1.4 -fold longer than that of $l$-esmolol after incubation with dog blood, whereas no stereoselective difference was found in human blood.

3. The concentration in the heart showed no significant difference between two enantiomers after administration of ${ }^{14} \mathrm{C}$-esmolol to rats.

4. The chiral inversion was found neither in blood after administration of ${ }^{14} \mathrm{C}-d$-esmolol or ${ }^{14} \mathrm{C}-l$-esmolol to dogs nor in human and dog blood after the in vitro incubation.

5. There was no significant difference in protein bindings of each enantiomer after the in vitro incubation with human, dog and rat serum, and the bound fraction was the highest in human, followed by dog and rat serum.

In conclusion, these findings suggest that pharmacokinetics of enantiomers slightly differ in dog, whereas there are no stereoselective differences in human blood kinetics.

\section{Key words: Esmolol, Enantiomer, Rat, Dog, Human, Intravenous administration, Protein binding}

\section{緒言}

Esmolol は, Dupont Merck 社において開発された心 蔵に対して高い選択性を有する超短時間作用型 $\beta$ 遮断 薬であり，分子内に不斉炭素を 1 原子有したラセミ体 である1,2)。この超短時間作用は血中エステラーゼによ る急速な酵素的加水分解によることが報告されてい $ろ^{3-5)}$. Esmolol の体内動態はラセミ体としての試験成 績が主に報告されており 4,5$)$, 光学異性体間での体内動 態の比較については明らかにされていない。そこで本研
究では, 血液および心臓中のエスモロール光学異性体に ついて光学分割カラムを用いた分離定量法を確立し, ${ }^{14} \mathrm{C}$ 標識 $\mathrm{esmolol}$ を静脈内投与したときのイス血液中動 態およびラット心臓中濃度推移ならびにイスおよびヒト 血液中での in vitro 代謝について光学異性体間で比較す るとともに，イヌおよびヒト血液中での光学異性体相互 変換についても検討した．また血清中のエスモロール定 量法を確立し，ラット，イヌ抢よびヒトの血清蛋白結合 率について光学異性体間で比較した.

丸石製薬株式会社 中央研究所 $\bar{T}$ 538-0042 大阪市鶴見区今津中 2-2-18

* 株式会社ネモト・サイエンス つくば研究所 薬物動態研究グループ テ300-2521 茨城県水海道市大生郷町字中丸 6136-4 
<smiles>COC(=O)Cc1ccc(OC[C@@H](O)CN=C(C)C)cc1</smiles>

Fig. 1 Chemical structure of ${ }^{14} \mathrm{C}$-esmolol * : Labeled position with ${ }^{14} \mathrm{C}$ $\star$ : Chiral center

\section{実験材料および方法}

\section{1. 実験材料}

\section{1) 標識化合物}

${ }^{14} \mathrm{C}$ 標識 esmolol ( ${ }^{14} \mathrm{C}$-esmolol : Lot No. M-990630 および $\mathrm{M}-000229),{ }^{14} \mathrm{C}$ 標識 $d$-esmolol $\left({ }^{14} \mathrm{C}-d\right.$-esmolol : Lot No. M-990812-D) および ${ }^{14} \mathrm{C}$ 標識 $l$-esmolol ${ }^{14} \mathrm{C}-l$-esmolol : Lot No. M-990806-L) は株式会 社ネモト・サイエンスで合成されたものを使用した (Fig. 1). 比放射能はいずれも $6.24 \mathrm{MBq} / \mathrm{mg}$ であり, TLC および HPLC で測定した放射化学的純度はいずれ も 97\%以上であった。

\section{2) 非標識化合物}

非標識 esmolol（esmolol：Lot No. Ru082 および Ru074, 含量 : 100.0\%) は Finorga 社で, 非標識 $d$-esmolol ( $d$-esmolol : Lot No. C97056-4, 含量 : $96.8 \%$, 光学的純度 $95.1 \%$ ) および非標識 $l$-esmolol ( $l$-esmolol : Lot No. C97056-2, 含量 : 97.8\%, 光学的純度 : 93.6 \%)は侏東レリサーチセンターで合成されたものを使用 した.

\section{3）試薬}

高速液体クロマトグラフィー(HPLC)の内標準物質に は $l$-塩酸プロプラノロール(アルドリッチ社) 扎よび $\mathrm{p}-$ ヒドロキシ安息香酸メチル(和光純薬)を，その他の試薬 は HPLC 用または市販特級品を使用した.

\section{2. 実験動物および生体試料}

\section{1）実験動物}

血液中動態試験には雄性の TOYO ビーグル $(10$ カ月 㱓, 体重 $10.8 \sim 12.2 \mathrm{~kg}$ : (侏北山ラベス) を用いた。動物 は温度 $22 \sim 30^{\circ} \mathrm{C}$, 湿度 $55 \sim 93 \%$, 換気回数 10 回以上/ 時間， 7〜19 時なでの 12 時間照明の環境下で，ステン レス製飼育ケーシ $(685 \mathrm{~W} \times 735 \mathrm{D} \times 650 \mathrm{Hmm})$ に 1 匹ず つ収容して飼育した。飼料は DS-5（オリエンタル酵母） を 1 日 1 回約 $250 \mathrm{~g}$ 与光, 水は水道水を自由に摄取させ た。

組織 (心葴) 分布試験には雄性の SD 系ラット（7 週 齡, 体重 $224 \sim 269 \mathrm{~g}$ : (㧣日本チャールス・リバー)を用
いた. 動物は温度 $23 \sim 25^{\circ} \mathrm{C}$, 湿度 $32 \sim 87 \%$, 換気回数 10 回以上/時間, 7〜 19 時までの 12 時間照明の環境下 で，金網床金属製ケージ $(239 \mathrm{~W} \times 200 \mathrm{D} \times 195 \mathrm{Hmm})$ に 1〜 5 匹ずつ収容し，投与後は 1 匹ずつ収容した。飼料 は CE-2(俳日本クレア)を, 水は水道水を自由に摂取さ せた.

\section{2) 生体試料}

分析法バリデーションおよび in vitro 代謝実験には, 雄性ビーグル (1 歳 2 力月〜 6 歳 1 力月齢; (侏ナルク) お よび男性ボランティア $(20 \sim 25$ 歳)の血液(ヘパリン処理 済)を使用した。

血清蛋白結合率の測定には SD 系雄性ラット（7 週 齢; 侏日本 SLC)，雄性ビーグル(侏日本クレア) および 男性ボランティア $(24 \sim 36$ 歳)の血清を使用した.

\section{In Vivo における体内動態}

1）投与液の調製および投与

イヌの試験では ${ }^{14} \mathrm{C}$-esmolol, ${ }^{14} \mathrm{C}$ - $d$-esmolol および ${ }^{14} \mathrm{C}-l$-esmolol をそれぞれの非標識体とともに注射用蒸 留水に溶解し, $50 \mathrm{mg} / \mathrm{mL}\left({ }^{14} \mathrm{C}\right.$-esmolol : $8.85 \mathrm{MBq} /$ $\mathrm{mL},{ }^{14} \mathrm{C}-d$-esmolol : $8.95 \mathrm{MBq} / \mathrm{mL},{ }^{14} \mathrm{C}$ - $l$-esmolol : $9.15 \mathrm{MBq} / \mathrm{mL})$ の溶液を調製し，それぞれ $10 \mathrm{mg} / 0.2$ $\mathrm{mL} / \mathrm{kg}$ の用量で橈側皮静脈内に投与した.

ラットの試験では ${ }^{14} \mathrm{C}$-esmolol を非標識体とともに生 理食塩液に溶解し, $20 \mathrm{mg} / \mathrm{mL}(3.90 \mathrm{MBq} / \mathrm{mL})$ の溶液 を調製し， $20 \mathrm{mg} / \mathrm{mL} / \mathrm{kg}$ の用量で尾静脈内に投与した.

\section{2）生体試料の採取}

イヌの試験では ${ }^{14} \mathrm{C}$-esmolol を静脈内投与後 $2,5,10$, 20, 30 分および 1 時間後に, ${ }^{14} \mathrm{C}-d$-esmolol あるいは ${ }^{14} \mathrm{C}-\mathrm{l}$-esmolol は静脈内投与後 5,20 分， 1,4 および 8 時間後に橈側皮静脈から 2 3 mL 採血した.

ラットの試験では ${ }^{14} \mathrm{C}$-esmolol t静脈内投与後 2,5 , 20 分および 2 時間後にエーテル麻酔下, 腹大動脈より 脱血致死させ，心臓を摘出した.

\section{3） $\boldsymbol{d}$-esmolol および $\boldsymbol{l}$-esmolol 濃度の測定}

イヌ血液およびラット心蔵を前処理後, HPLC で光 学異性体を分離した。得られた溶出液を放射能測定用容 器に分取し, 液体シンチレータ Hionic-Fluor (Packard) を加えて放射能を測定した。

\section{In Vitro における代謝実験}

イスまたはヒト血液 $0.5 \mathrm{~mL}$ を $15 \mathrm{~mL}$ 遠心チューブに 取り, $37^{\circ} \mathrm{C}$ で 5 分間プレインキュベートした後, $d$-esmolol または $l$-esmolol を 5 および $20 \mu \mathrm{g} / \mathrm{mL}$ となるよ うに添加して反応を開始した。インキュベーション時間 は $0,5,10,20,40$ および 60 分間とし，所定時間インキ ュベート後, 水中に移してジクロロメタンを加えて反応 を停止させた。 反応液に内標準物質 (I.S.)を加えて前処 
理し, HPLCで光学異性体を分離測定した。

\section{In Vitro における血清蛋白結合率}

ラット，イヌをたはヒト血清 $1.9 \mathrm{~mL}$ を $15 \mathrm{~mL}$ 遠心チ ューブに取り， $37^{\circ} \mathrm{C}$ で 2 分間プレインキュベートした 後， $d$-esmolol または $l$-esmolol を $0.2,0.5,2$ および 5 $\mu \mathrm{g} / \mathrm{mL}$ となるように添加して反応を開始した. 2 分間 のインキュベーション後, その $1.0 \mathrm{~mL}$ をセントリフ リーMPS-3(アミコン)に取り, 遠心分離( $2000 \mathrm{~g}, 20$ 分間)した。遠心分離後の濾液に $\mathrm{p}$ 一ヒドロキシ安息香酸 メチル (I.S.)を加えて, HPLC でエスモロール濃度を測 定した。

\section{6. 試料の前処理}

\section{1）血液}

In vivo 試験ではイヌ血液 $200 \mu \mathrm{L}$ にアセトニトリル $400 \mu \mathrm{L}$ t添加後, 遠心分離 (7200 g, 5 分間) し, 得ら れた上清 $400 \mu \mathrm{L}$ に esmolol 水溶液 $(1 \mathrm{mg} / \mathrm{mL})$ を $40 \mu \mathrm{L}$ 添加した。この試料 $100 \mu \mathrm{L}$ を HPLCに供した。

In vitro 試験ではイヌまたはヒト血液 $0.5 \mathrm{~mL}$ に, シ クロロメタン $5 \mathrm{~mL}, 0.2 \mathrm{M}$ 水酸化ナトリウム溶液 50 $\mu \mathrm{L}$, 内標準物質 (I.S.) として $l$-塩酸プロプラノロール溶 液 $(50 \mu \mathrm{g} / \mathrm{mL}) 10 \mu \mathrm{L}$ を加え, 10 分間振盪後, 遠心分離 (2000 rpm，10 分間) した. 有機相を分取し， $0.02 \mathrm{M}$ 水 酸化ナトリウム溶液 $5 \mathrm{~mL}$ を加え, さらに 10 分間振盪 後, 遠心分離 (2000 rpm, 10 分間) した. 有機相を分取 L, $0.025 \mathrm{M}$ 硫酸溶液 $200 \mu \mathrm{L}$ を加え, 1 分間振盪後, 遠心分離(2000 rpm, 5 分間) し, 得られた水相 $50 \mu \mathrm{L}$ を HPLC に供した ${ }^{6)}$.

\section{2) 心 臟}

ラット心臓に $62.5 \mu \mathrm{g} / \mathrm{mL}$ の esmolol を含む $10 \mathrm{mM}$ フッ化ナトリウム水溶液を加えて $20 \%$ ホモジネートを 調製した。そのうち $400 \mu \mathrm{L}$ にアセトニトリル $800 \mu \mathrm{L}$ を加え, 遠心分離(1500 g, 10 分間)して上清を取り， さらに沈椬にアセトニトリル $800 \mu \mathrm{L}$ を加えて遠心分離 (1500 g，10 分間) した上清と合わせた。これを窒素気 流下で乾固後, HPLC 移動相 $100 \mu \mathrm{L}$ を加えて溶かし， その $50 \mu \mathrm{L}$ を HPLCに供した.

\section{3）血清}

ラット，イヌおよびヒト血清 $0.6 \mathrm{~mL}$ に水 $0.9 \mathrm{~mL}$ を 加えて混和した後, その $1.25 \mathrm{~mL}$ を Sep-pak $\mathrm{C}_{18}$ light (日本ウォーターズ)に注入し， $0.25 \mathrm{mM}$ リン酸水溶液 $2 \mathrm{~mL}$ で洗浄した。 $0.25 \mathrm{mM}$ リン酸水溶液ーアセトニト リル $(70: 30 \mathrm{v} / \mathrm{v}) 0.5 \mathrm{~mL}$ で溶出し, その $0.39 \mathrm{~mL}$ に I.S. として p-ヒドロキシ安息香酸メチル $(40 \mu \mathrm{g} / \mathrm{mL}) 10$ $\mu \mathrm{L}$ を加え, $100 \mu \mathrm{L}$ をHPLC に供した。

\section{HPLC 条件}

\section{1）光学異性体分離測定}

In vivo 試験ではポンプ Model 305 (GILSON), カラ ムオープン L-7300 (日立), 紫外検出器 L-7420 (日立) で構成された HPLC システムを使用し，試料の注入に はインジェクタ 7725i (Rheodyne)を使用した.

In vitro 試験ではポンプ CCPM-II (東ソー)，オート サンプラーAS-8020 (東ソー), カラムオーブン AO30C (昭和電工), 紫外検出器 UV-8011(東ソ一) 㧍よび データ処理ソフト LC-8020(東ソー) で構成された HPLC システムを使用した.

カラムは Chiral CD-Ph (4.6 mm I.D. × $250 \mathrm{~mm}$; 資 生堂）を使用し，イスおよびラット試料は移動相に過塩 素酸ナトリウム溶液/アセトニトリル $(50: 50 \mathrm{v} / \mathrm{v})$ を用 いて流速 $0.7 \mathrm{~mL} / \mathrm{min}$ で，ヒト試料は過塩素酸ナトリウ ム溶液/アセトニトリル $(55: 45 \mathrm{v} / \mathrm{v})$ を用いて流速 0.5 $\mathrm{mL} / \mathrm{min}$ で溶出させ, ともに UV $229 \mathrm{~nm}$ で検出した.

\section{2）エスモロール濃度測定}

HPLC システムはポンプ CCPM-II (東ソー)，オート サンプラー AS- 8020 (東ソー)，カラムオーブン CO8020 (東ソー), 紫外検出器 UV-8020 (東ソー) および データ処理装置 SC-8020 (東ソー) で構成されたものを 使用した。 カラムは TSK-gelODS-80Ts (4.6 mm I.D. $\times 250 \mathrm{~mm}$; 東ソー) を使用し, $\mathrm{A}$ 液に $0.02 \mathrm{M}$ リン酸緩 衝液 $(\mathrm{pH} 4.0)$ を，B液にアセトニトリル $-0.02 \mathrm{M}$ リン酸 緩衝液 $(80: 20 \mathrm{v} / \mathrm{v})$ を用いたグラジエント (Table I) に より流速 $1.0 \mathrm{~mL} / \mathrm{min}$ で溶出させ, UV $229 \mathrm{~nm}$ で検出 した.

\section{8. 放射能の測定}

放射能は液体シンチレーションカウンタ LCS-3500 (Aloka) , LCS-5100（Aloka）または LS6000（Beckman)により 5 分間測定した. 計数効率は外部標準線源 法により補正し, 定量限界值はバックグランド値の 2 倍とした。

\section{9. 試験成績の表示}

\section{1）イヌにおける血液中動態}

血液中濃度は各試料中の放射能の計数値から算出した。

Table I Gradient condition of HPLC for esmolol quantitation

\begin{tabular}{ccc}
\hline Time $(\min )$ & A sol. (\%) & B sol. (\%) \\
\hline 0.0 & 78 & 22 \\
14.0 & 55 & 45 \\
14.5 & 0 & 100 \\
19.5 & 0 & 100 \\
20.0 & 78 & 22
\end{tabular}


${ }^{14} \mathrm{C}$-esmolol を投与して求めた血液中 $d$-esmolol および $l$-esmolol 濃度值から, 薬物動態パラメータとして半減 期 $\left(\mathrm{t}_{1 / 2}\right)$ および血液中濃度一時間曲線下面積 (AUC) を Win Nonlin (Ver. 1.1; Parsight Corporation)により算出 した. 数值は平均值および標準偏差(S.D.)で示した．例 数の過半数の個体が定量限界末満の場合は平均值を定量 限界未満として表示し, 半数以下の個体が定量限界末満 の場合には, 定量限界未満の個体值を 0 として平均値 を算出した.

\section{2）ラットにおける心臓中濃度推移}

心臓中濃度は各試料中の放射能の計数值から esmolol 当量に換算して表示し, 平均值および S.D. で示した. 例数の過半数の個体が定量限界末満の場合は平均值を定 量限界未満として表示し, 半数以下の個体が定量限界末 満の場合には, 定量限界末満の個体值を 0 として平均 值を算出した.

\section{3）In vitroにおける代謝}

血液中の $d$-esmolol および $l$-esmolol 量は, 各光学異 性体と I.S. とのピーク面積比で示し, インキュベーシ ヨン時間を X, ピーク面積比の常用対数を Y として最 小二乗法による一次回帰分析を行い, 傾き (Slope) から 下記の式により半減期 $\left(\mathrm{t}_{1 / 2}\right)$ を求めた.

$$
\mathrm{t}_{1 / 2}=-\log 2 / \text { Slope }
$$

\section{4）In vitroにおける血清蛋白結合率}

血清蛋白結合率は, 各光学異性体の調製濃度 $(\mathrm{Ct})$ と 測定した血清濾液中の $d$-esmolol および $l$-esmolol 濃度 值 (非結合型濃度 : Cf) から下記の式により算出し, 平 均值および S.D. で示した.
血清蛋白結合率 $(\%)=(\mathrm{Ct}-\mathrm{Cf}) / \mathrm{Ct} \times 100$

\section{結果}

1. 分析法バリデーション

\section{1）血液中光学異性体の分離定量}

イヌおよびヒト血液に $d$-esmolol, $l$-esmolol および I.S. を添加したときのクロマトグラムを Fig. 2 に, 分 析能パラメータを Table II に示した. イヌでは $l$-esmolol は 8.40 分, $d$-esmolol は 9.30 分, I.S. は 10.23 分 に溶出され, これらのピークの溶出位置に妨害する内因 性夾雑物のピークは認められず, $l$-esmolol と $d$-esmolol および $d$-esmolol と I.S. の分離度はそれぞれ 2.63 および 2.55 であった. 相関係数は $0.25 〜 10 \mu \mathrm{g} / \mathrm{mL}$ (定 量限界値 : $d$-esmolol, $l$-esmolol ともに $0.25 \mu \mathrm{g} / \mathrm{mL}$ )の 範囲で $d$-esmolol, $l$-esmolol ともに 1.000 であり, 良好 な直線性を示した．変動係数(C.V.\%)は 0.25〜 $10 \mu \mathrm{g}$ / $\mathrm{mL}$ の範囲で $d$-esmolol が $1.0 \sim 4.8 \%, l$-esmolol が 1.0 〜 2.3\%であり, 血液からの回収率は $d$-esmolol が 88.4 〜93.8\%, l-esmolol が 82.3〜88.8\%であった.

ヒトでは $l$-esmolol は 12.56 分, $d$-esmolol は 13.76 分, I.S. は 15.74 分に溶出され, これらのピークの溶出 位置に妨害する内因性夾雑物のピークは認められず， $l-$ esmolol とd-esmolol および $d$-esmolol と I.S.の分離度 はそれぞれ 2.73 および 4.19 であった．相関係数は 0.25 $\sim 15 \mu \mathrm{g} / \mathrm{mL}$ (定量限界值 : $d$-esmolol, $l$-esmolol ともに $0.25 \mu \mathrm{g} / \mathrm{mL}$ ) の範囲で $d$-esmolol, $l$-esmolol ともに 1.000 であり, 良好な直線性を示した. C.V. 值は 0.25 $\sim 15 \mu \mathrm{g} / \mathrm{mL}$ の範囲で $d$-esmolol が $1.0 \sim 4.0 \%, l$-es-

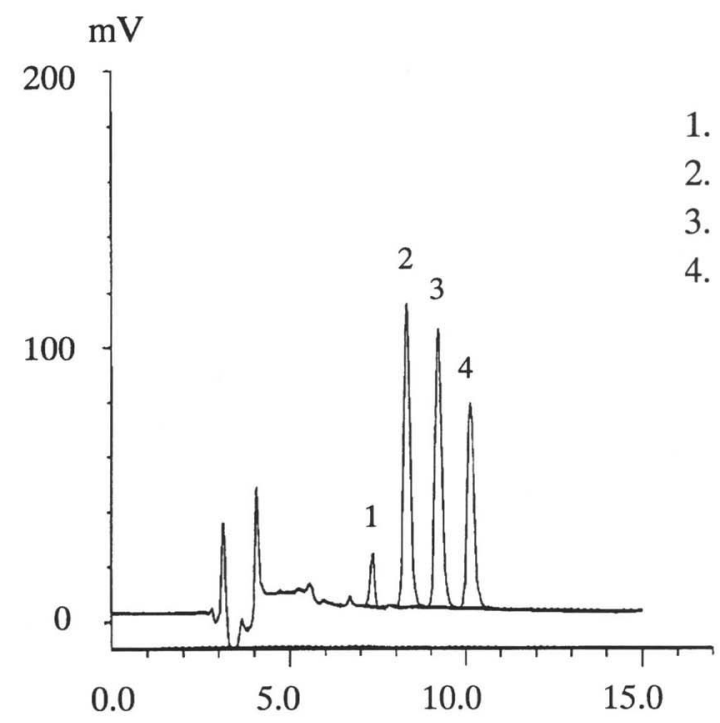

1. Blank peak

2. $l$-esmolol

3. $d$-esmolol

4. I.S.

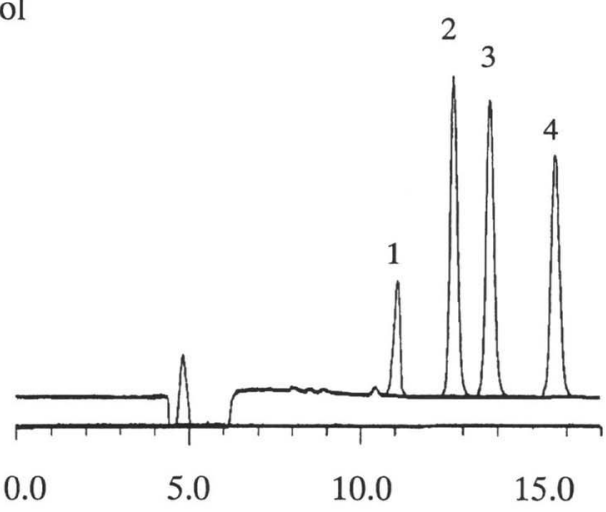

Retention time (min)

Fig. 2 HPLC chromatograms obtained from dog (left) and human (right) blood added $d$-esmolol $(5 \mu \mathrm{g} / \mathrm{mL}), l$-esmolol (5 $\mu \mathrm{g} / \mathrm{mL})$ and I.S. $(1 \mu \mathrm{g} / \mathrm{mL})$ 
Table II Variability of an analytical method and recovery of an analyte in an assay (blood)

\begin{tabular}{|c|c|c|c|c|c|}
\hline \multirow{2}{*}{ Species } & \multirow{2}{*}{$\begin{array}{c}\text { Conc. } \\
(\mu \mathrm{g} / \mathrm{mL})\end{array}$} & \multicolumn{2}{|c|}{$d$-esmolol } & \multicolumn{2}{|c|}{$l$-esmolol } \\
\hline & & C.V. (\%) & Recovery (\%) & C.V. $(\%)$ & Recovery (\%) \\
\hline \multirow{3}{*}{ Dog } & 0.25 & 4.8 & 93.8 & 2.3 & 82.3 \\
\hline & 2.5 & 1.2 & 88.4 & 1.2 & 88.6 \\
\hline & 10 & 1.0 & 88.5 & 1.0 & 88.8 \\
\hline \multirow{3}{*}{ Human } & 0.25 & 4.0 & 97.3 & 3.2 & 97.0 \\
\hline & 5 & 1.0 & 90.3 & 0.8 & 90.5 \\
\hline & 15 & 2.1 & 89.2 & 2.1 & 89.0 \\
\hline
\end{tabular}

Each value represents the mean $(n=5)$.

Table III Variability of an analytical method and recovery of an analyte in an assay (serum)

\begin{tabular}{lccc}
\hline Species & $\begin{array}{c}\text { Conc. } \\
(\mu \mathrm{g} / \mathrm{mL})\end{array}$ & $\begin{array}{c}\text { C.V. } \\
(\%)\end{array}$ & $\begin{array}{c}\text { Recovery } \\
(\%)\end{array}$ \\
\hline \multirow{3}{*}{ Rat } & 0.2 & 3.0 & 95.7 \\
& 1 & 6.6 & 82.6 \\
& 5 & 2.0 & 81.9 \\
\multirow{3}{*}{ Dog } & 0.2 & 2.9 & 112.0 \\
& 1 & 3.4 & 95.4 \\
& 5 & 3.2 & 102.6 \\
\multirow{3}{*}{ Human } & 0.2 & 3.0 & 108.5 \\
& 1 & 3.2 & 98.8 \\
& 5 & 4.0 & 100.0 \\
\hline
\end{tabular}

Each value represents the mean $(n=5)$.

molol が 0.8〜 3.2\%であり, 血液からの回収率は $d$-esmolol が 89.2 97.3\%, l-esmolol が 89.0〜97.0\%であ った.

\section{2）血清中エスモロールの定量}

ラット，イヌおよびヒト血清中エスモロール定量法の 分析能パラメータを Table III に示した. いずれの血清 試料においても esmolol および I.S.の溶出位置に妨害す る内因性夾雑物のピークは認められず，相関係数は 0.1 $\sim 5 \mu \mathrm{g} / \mathrm{mL}$ の範井(定量限界：ラット，イスおよびヒト ともに $0.2 \mu \mathrm{g} / \mathrm{mL}$ ) でラット，イヌおよびヒトともに 0.999〜 1.000 であった. C.V. 值は $0.2 \sim 5 \mu \mathrm{g} / \mathrm{mL}$ の範 囲でラット，イヌおよびヒトでそれぞれ 2.0〜 6.6\%， 2.9〜3.4\% および 3.0〜 4.0\%であった．血清からの esmolol の回収率は, ラットで 81.9 95.7\%, イスで 95.4 〜112.0\%, ヒトで98.8～108.5\%であった.

\section{2. イヌにおける血液中動態}

イヌに ${ }^{14} \mathrm{C}$-esmolol を $10 \mathrm{mg} / 0.2 \mathrm{~mL} / \mathrm{kg}$ の用量で単 回静脈内投与後の $d$-esmolol および $l$-esmolol 血液中濃 度推移を Fig. 3 に, 薬物動態パラメータを Table IV に示した。 ${ }^{14} \mathrm{C}$-esmolol を投与 2 分後の血液中 $d$-esmolol および $l$-esmolol 濃度はそれぞれ $1.26 \mu \mathrm{g} / \mathrm{mL}$ お

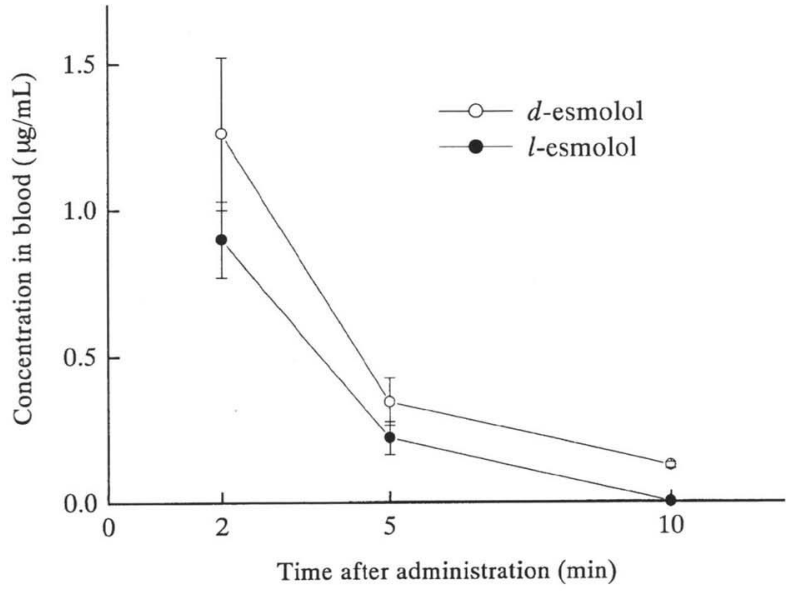

Fig. 3 Concentration of $d$-esmolol and $l$-esmolol in blood after an intravenous administration of ${ }^{14} \mathrm{C}$-esmolol to male dogs

Each point represents the mean \pm S.D. $(n=3)$.

Table IV Phamacokinetic parameters of $d$-esmolol and $l$-esmolol after an intravenous administration of ${ }^{14} \mathrm{C}$-esmolol to male dogs

\begin{tabular}{lcc}
\hline & $d$-esmolol & $l$-esmolol \\
\hline $\mathrm{T}_{1 / 2}(\mathrm{~min})$ & $2.5 \pm 0.2$ & $1.5 \pm 0.1$ \\
\hline $\mathrm{AUC}(\mu \mathrm{g} \cdot \mathrm{hr} / \mathrm{mL})$ & $0.137 \pm 0.026$ & $0.089 \pm 0.012$ \\
\hline
\end{tabular}

Each value represents the mean \pm S.D. $(n=3)$.

よび $0.899 \mu \mathrm{g} / \mathrm{mL}$ で, その後 $d$-esmolol は 2.5 分, $l-$ esmolol は 1.5 分の半減期で減少した. $d$-esmolol は投 与 20 分後, $l$-esmolol は投与 10 分後には定量限界末満 となり，l-esmolol の方が $d$-esmolol より血液からの消 失は速かった(1.7 倍)。いずれの測定時点においても血 液中の $d$-esmolol 濃度は $l$-esmolol 濃度より高く, AUC は $d$-esmolol $(0.137 \mu \mathrm{g} \cdot \mathrm{hr} / \mathrm{mL})$ の方が $l$-esmolol $(0.089$ $\mu \mathrm{g} \cdot \mathrm{hr} / \mathrm{mL})$ より 1.6 倍高かった。

イヌに ${ }^{14} \mathrm{C}-d$-esmolol あるいは ${ }^{14} \mathrm{C}$ - $l$-esmolol を 10 $\mathrm{mg} / 0.2 \mathrm{~mL} / \mathrm{kg}$ の用量で単回静脈内投与後の $d$-esmolol および $l$-esmolol 血液中濃度を Table V に示した。 ${ }^{14} \mathrm{C}-$ 
$d$-esmolol を投与 5 分後の血液中 $d$-esmolol 濃度は $0.504 \mu \mathrm{g} / \mathrm{mL}$ を示し, 投与 20 分後には定量限界末満上 なり，l-esmolol はいずれの測定時点においても認めら れなかった。 ${ }^{14} \mathrm{C}-l$-esmolol を投与 5 分後の血液中 $l$-esmolol 濃度は $0.093 \mu \mathrm{g} / \mathrm{mL}$ を示し, 投与 20 分後には定 量限界末満となり, $d$-esmolol はいずれの測定時点にお いても認められなかった。

\section{In Vitroににおける血清蛋白結合率}

ラット，イスあるいはヒト血清に $0.2,0.5,2$ および 5 $\mu \mathrm{g} / \mathrm{mL}$ となるように $d$-esmolol あるいは $l$-esmolol を添 加したときの $d$-esmolol 抢よび $l$-esmolol の血清蛋白結 合率を Table VI に示した. ラットにおける血清蛋白結 合率は $d$-esmolol で 27.9 29.3\%, l-esmolol で 25.6〜 31.7\%，イヌではそれぞれ 37.0〜 41.5\%，35.4〜36.3 \%，ヒトではそれぞれ 37.6〜39.0\%，42.1～46.4\% と 0.2 $5 \mu \mathrm{g} / \mathrm{mL}$ の濃度範囲でほぼ一定の值を示した。 ど の種においても光学異性体間で蛋白結合率に顕著な差は 認められず，いずれも比較的低值であった．また，血清 蛋白に対する結合率はヒト，イヌ，ラットの順に高かっ た.

\section{4. ラットにおける心臓中濃度推移}

ラットに ${ }^{14} \mathrm{C}$-esmolol を $20 \mathrm{mg} / \mathrm{mL} / \mathrm{kg}$ の用量で単回

Table V Concentration of each enantiomer in blood after an intravenous administration of ${ }^{14} \mathrm{C}-d$-esmolol or ${ }^{14} \mathrm{C}$ - $l$-esmolol to male dogs

\begin{tabular}{cccccc}
\hline \multirow{2}{*}{ Time } & \multicolumn{2}{c}{$\begin{array}{c}\text { Administration of } \\
{ }^{14} \mathrm{C}-d-\text { esmolol }\end{array}$} & & \multicolumn{2}{c}{$\begin{array}{c}\text { Administration of } \\
{ }^{14} \mathrm{C}-l-\text { esmolol }\end{array}$} \\
\cline { 2 - 3 } \cline { 6 - 7 } & $\begin{array}{c}d \text {-esmolol } \\
(\mu \mathrm{g} / \mathrm{mL})\end{array}$ & $\begin{array}{c}l \text {-esmolol } \\
(\mu \mathrm{g} / \mathrm{mL})\end{array}$ & & $\begin{array}{c}d \text {-esmolol } \\
(\mu \mathrm{g} / \mathrm{mL})\end{array}$ & $\begin{array}{c}l \text {-esmolol } \\
(\mu \mathrm{g} / \mathrm{mL})\end{array}$ \\
\hline $5 \mathrm{~min}$ & 0.504 & $<\mathrm{LOQ}$ & & $<\mathrm{LOQ}$ & 0.093 \\
$20 \mathrm{~min}$ & $<\mathrm{LOQ}$ & $<\mathrm{LOQ}$ & & $<\mathrm{LOQ}$ & $<\mathrm{LOQ}$ \\
$1 \mathrm{hr}$ & $<\mathrm{LOQ}$ & $<\mathrm{LOQ}$ & & $<\mathrm{LOQ}$ & $<\mathrm{LOQ}$ \\
$4 \mathrm{hr}$ & $<\mathrm{LOQ}$ & $<\mathrm{LOQ}$ & & $<\mathrm{LOQ}$ & $<\mathrm{LOQ}$ \\
$8 \mathrm{hr}$ & $<\mathrm{LOQ}$ & $<\mathrm{LOQ}$ & & $<\mathrm{LOQ}$ & $<\mathrm{LOQ}$ \\
\hline
\end{tabular}

$<\mathrm{LOQ}$ : Below the limit of quantitation

Each value represents the mean $(n=2)$.
静脈内投与後の $d$-esmolol および $l$-esmolol 心臓中濃度 推移を Fig. 4 に示した. ${ }^{14} \mathrm{C}$-esmolol を投与 2 分後の心 蔵中 $d$-esmolol および $l$-esmolol 濃度はそれぞれ 13.1 $\mu \mathrm{g} / \mathrm{g}$ および $12.5 \mu \mathrm{g} / \mathrm{g}$ で, その後 $d$-esmolol, $l$-esmolol ともにほぼ同一の速度で速やかに減少し, 投与 20 分後 にはいずれも $0.5 \mu \mathrm{g} / \mathrm{g}$ まで低下した。臟への分布量 およびその濃度推移に光学異性体間で差はなかった。 な お本法による心蔵からの $d$-esmolol および $l$-esmolol の 回収率は 96.0 98.2\%であった。

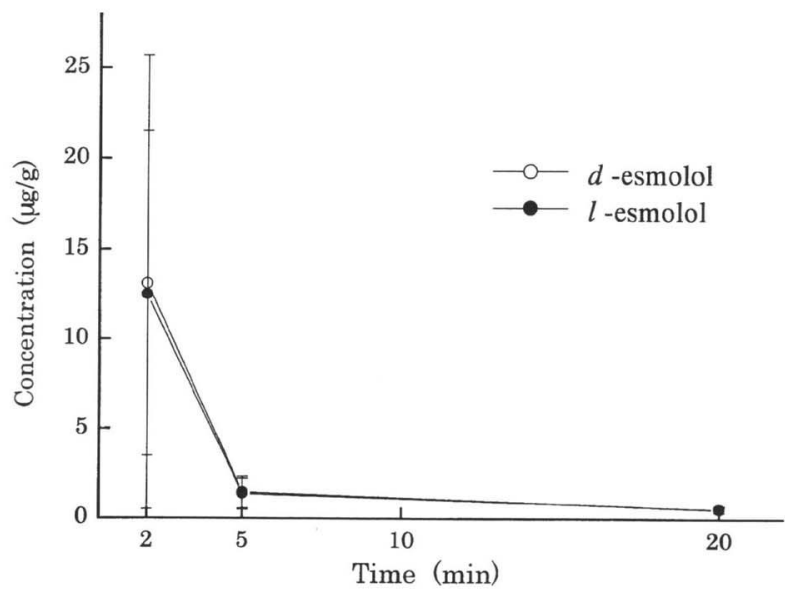

Fig. 4 Concentration of each enantiomer in heart after an intravenous administration of ${ }^{14} \mathrm{C}$-esmolol to male rats Each point represents the mean \pm S.D. $(n=3)$.

Table VII The half-lives of $d$-esmolol and $l$-esmolol in dog and human blood (in vitro)

\begin{tabular}{lcc}
\hline \multirow{2}{*}{ Species } & \multicolumn{2}{c}{$\mathrm{T}_{1 / 2}(\mathrm{~min})$} \\
\cline { 2 - 3 } & $d$-esmolol & l-esmolol \\
\hline Dogi $^{1)}$ & 18.7 & 13.7 \\
Human $^{2)}$ & 34.8 & 33.1 \\
\hline
\end{tabular}

1) The values were obtained from the pooled sample $(n=3)$.

2) The values represent the mean $(n=3)$.

Table VI Protein binding of $d$-esmolol and $l$-esmolol to serum protein

\begin{tabular}{|c|c|c|c|c|c|c|}
\hline \multirow{3}{*}{$\begin{array}{l}\text { Conc. } \\
(\mu \mathrm{g} / \mathrm{mL})\end{array}$} & \multicolumn{6}{|c|}{ Protein binding $(\%)$} \\
\hline & \multicolumn{3}{|c|}{$d$-esmolol } & \multicolumn{3}{|c|}{$l$-esmolol } \\
\hline & Rat & Dog & Human & Rat & Dog & Human \\
\hline 0.2 & $28.8 \pm 1.1$ & $37.9 \pm 2.3$ & $37.6 \pm 0.4$ & $31.7 \pm 1.5$ & $35.8 \pm 1.0$ & $43.9 \pm 1.6$ \\
\hline 0.5 & $27.9 \pm 1.3$ & $37.0 \pm 2.4$ & $37.6 \pm 2.9$ & $30.0 \pm 2.6$ & $36.3 \pm 0.4$ & $46.4 \pm 1.2$ \\
\hline 2 & $29.3 \pm 1.2$ & $40.9 \pm 2.4$ & $38.1 \pm 1.1$ & $26.6 \pm 0.7$ & $35.4 \pm 2.5$ & $42.1 \pm 1.5$ \\
\hline 5 & $28.2 \pm 0.9$ & $41.5 \pm 2.3$ & $39.0 \pm 2.8$ & $25.6 \pm 1.3$ & $35.7 \pm 2.5$ & $45.2 \pm 2.5$ \\
\hline
\end{tabular}

Each value represents the mean \pm S.D. $(n=3)$. 
(1) Dog

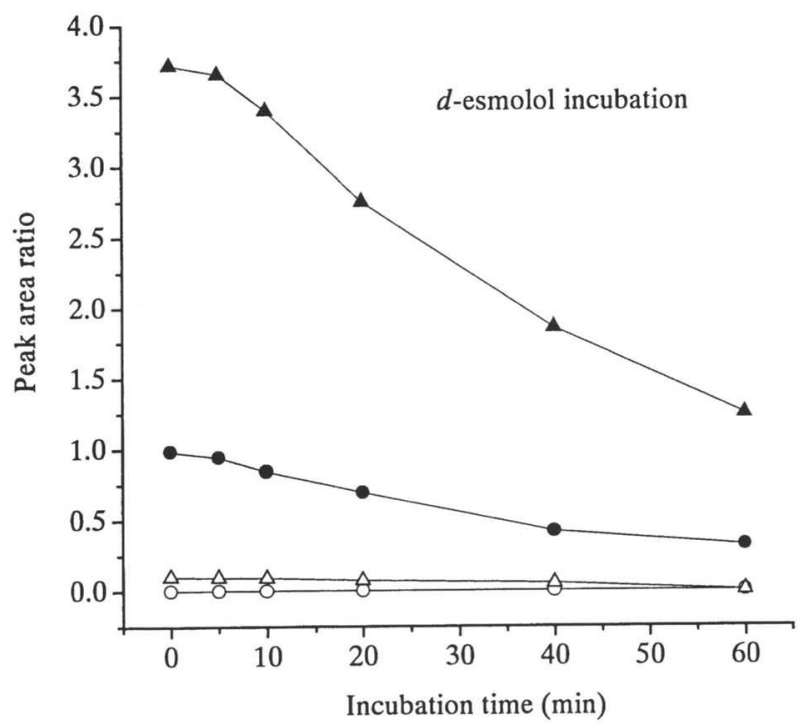

(2) Human

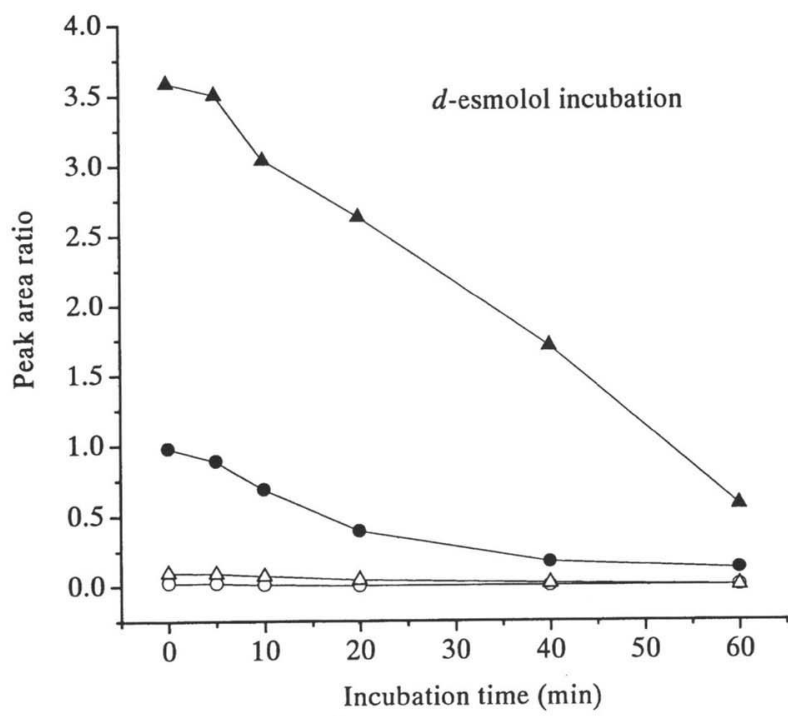

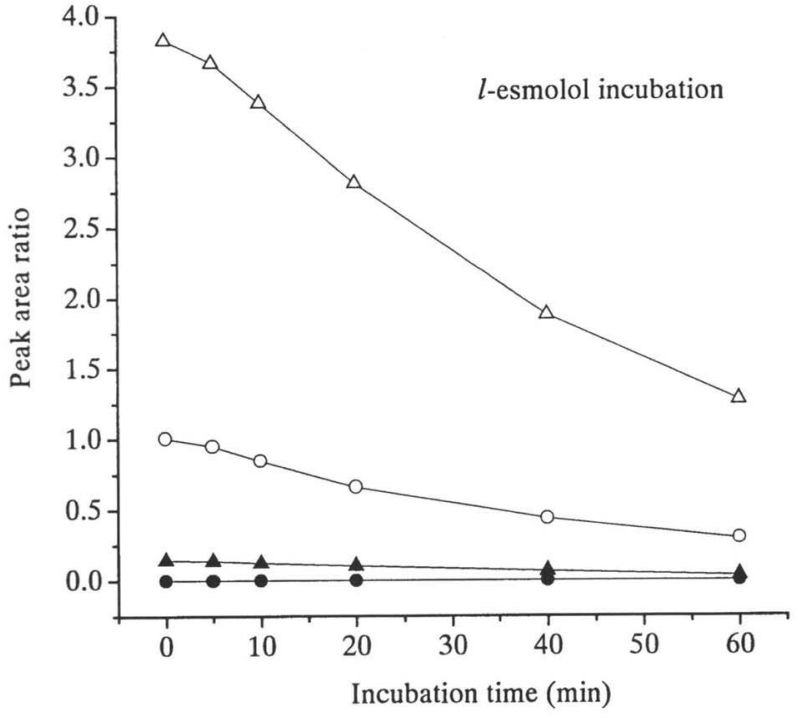

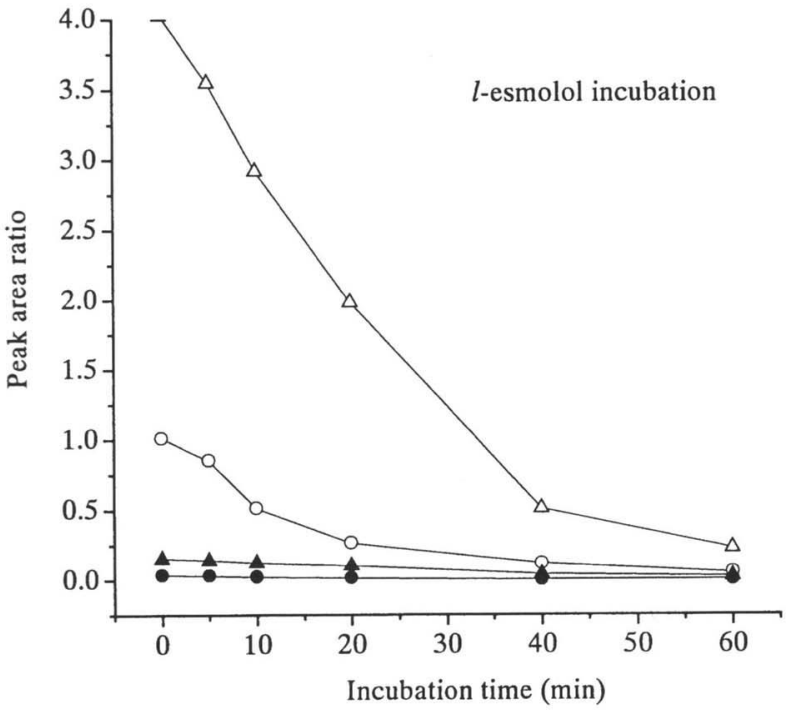

- $d$-esmolol $(20 \mu \mathrm{g} / \mathrm{mL}$ blood $)$ - $d$-esmolol $(5 \mu \mathrm{g} / \mathrm{mL}$ blood) $\triangle$ l-esmolol $(20 \mu \mathrm{g} / \mathrm{mL}$ blood $)$ -

Fig. 5 Peak area ratio for I.S. of $d$-esmolol and $l$-esmolol after incubation of $d$-esmolol and $l$-esmolol with dog (1) and human (2) blood Each point represents the mean $(n=3)$.

\section{In Vitroにおける代謝}

イヌあるいはヒト血液に 5 および $20 \mu \mathrm{g} / \mathrm{mL}$ となるよ うに $d$-esmolol あるいは $l$-esmolol を添加し， $37^{\circ} \mathrm{C}$ でイ ンキュベートした後の血液中 $d$-esmolol および $l$-esmolol 量の推移を Fig. 5 に, それぞれの半減期を Table
VII に示した. $d$-esmolol 抢よび $l$-esmolol をイ又ある いはヒト血液とインキュベートしたとき， $d$-esmolol は イヌで 18.7 分, ヒトで 34.8 分の半減期で, $l$-esmolol はイスで 13.7 分, ヒトで 33.1 分の半減期で減少し, い ずれの場合も相対する光学異性体の生成は認められなか 
った．血液中での $d$-esmolol および $l$-esmolol の半減期 はイヌの方がヒトより短かった。 また, イヌでは $l$-esmolol の方が $d$-esmolol より半減期は短く, ヒトでは光 学異性体間で差はみられなかった。

\section{考察}

イヌおよびヒト血液中光学異性体の分離定量法, ラッ ト心蔵中光学異性体の分離定量法およびラット，イス， ヒト血清中エスモロール定量法を確立し, これらの方法 を用いて ${ }^{14} \mathrm{C}$ 標識 esmolol $\left({ }^{14} \mathrm{C}\right.$-esmolol) を単回静脈内 投与したときのイスにおける血液中動態およびラットに おける心臓中濃度推移, 血液中 ( in vitro) での代謝なら びにラット, イヌ, ヒトでの血清蛋白結合率 (in vitro) について光学異性体間で比較検討し, さらにイ又血液中 (in vivo および in vitro) およびヒト血液中 (in vitro) での 光学異性体の相互変換について検討した.

イヌ血液中光学異性体の分離定量ではジクロロメタン による血液からの抽出と光学分割カラムを用いた分析法 により，血液中 $d$-esmolol 抢よび $l$-esmolol 濃度が 0.25 $\sim 10 \mu \mathrm{g} / \mathrm{mL}$ の範囲で良好な分離(分離度 2.63) と定量精 度 (変動係数 $8 \%$ 以下) が得られた。 ヒト血液では内因性 夾雑物の影響を避けるために，イヌ血液中の測定法とは 移動相の組成および流速を変えた条件で検討し, イヌと 同様な分析精度が得られた．ラット，イス，ヒト血清中 エスモロールの定量においても良好な分離精度を得た。

${ }^{14} \mathrm{C}$-esmolol をイヌに静脈内投与したときの光学異性 体の血液中動態に抒いて, $d$-esmolol の方が $l$-esmolol に比べ血液中濃度および AUC は高く, 半減期は $l$-esmolol (1.5 分) の方が $d$-esmolol (2.5 分)上り短かっ た. また，イ又血液中の in vitroでの半減期についても 同様に $l$-esmolol (13.7 分)のほうが $d$-esmolol (18.7 分）上り短かったことから，イス血液中におけるエステ ラーゼによる代謝には立体選択性があることが示され た. 一方, ヒト血液中の in vitro での半減期は, 光学異 性体間で差はみられず ( $d$-esmolol：34.8 分, l-esmolol : 33.1 分), ヒト生体内において光学異性体間の 消失半減期に差はないことが示唆された。これらの結果 は, esmolol の代謝酵素である血中エステラーゼの酵素 活性および立体選択性に種差があることを示唆しており， Quon らの報告7)に一致した。また，イ又血液中におけ る $d$-esmolol と $l$-esmolol の消失半減期は in vitroに比 ベin vivoで短く, ヒトにおいても in vivo (消失半減 期：9 分(4)の方が短かった. これはin vivoにおいて esmolol の分布容積が大きいこと年, in vivoの酵素活性は in vitroに比べて維持されていること，in vivoでは esmolol の加水分解代謝物が速やかに尿中に排泄される8) ため, 反応速度が減少しないこと等が原因として考えら れる.
血清蛋白に対する結合率はヒト (約 $41 \%$ )，イヌ(約 $37 \%$ ), ラット (約 29\%) の順に高く, どの種においても 0.2 $5 \mu \mathrm{g} / \mathrm{mL}$ の範囲内でほぼ一定の値を示した。 また ラット，イヌおよびヒト血清における $d$-esmolol と $l$ esmolol の蛋白結合率に光学異性体間で差は認められな かった.

${ }^{14} \mathrm{C}$-esmolol をラットに静脈内投与したときの心臓へ の分布量(投与 2 分後で約 $13 \mu \mathrm{g} / \mathrm{g}$ ) およびその濃度推移 は光学異性体間で差がなかった．膜通過が薬物の脂溶性 に基づく受動拡散の場合，物性が同等な光学異性体間で は分布に差は認められない，分布に差が認められるの は, 蛋白結合率に差がある場合や膜通過に担体輸送系が 関与している場合である ${ }^{9)}$. Esmolol の場合は蛋白結合 率に光学異性体間で差がなかったことから心蔵への移行 は脂溶性にのみ依存した受動拡散と考えられる。また, $d$-esmolol と $l$-esmolol の濃度推移に差が認められなか ったことから，心蔵中のエステラーゼによる立体選択的 代謝は血中エステラーゼほど顕著ではないものと推察さ れる。

${ }^{14} \mathrm{C}$ - $d$-esmolol あるいは ${ }^{14} \mathrm{C}-l$-esmolol をイスに単回 静脈内投与したときの血液中に，それぞれ相詨する光学 異性体は認められなかった。 また，イ又およびヒト血液 にd-esmolol あるいは $l$-esmolol を添加し, $37^{\circ} \mathrm{C}$ でイン キュベートしたときの血液中においても相対する光学異 性体の生成は認められなかったことから, ヒト生体内で esmolol の光学異性体変換は起こらないものと考えられ る。

一般に esmolol のような静脈内投与の薬物について光 学異性体間で体内動態に差が生じることの原因として は, 代謝酵素が立体選択性を有すること, 血液中で光学 異性体変換が起こること, 蛋白結合に起因する分布に差 があることなどが考えられる，本実験においてイヌ血液 中では esmolol の光学異性体変換が起こらないことおよ び蛋白結合率に差がないことが確認されたことから，光 学異性体間の血中動態の差は esmolol の代謝酵素である 血中エステラーゼの立体選択性に起因すると考えられ る. 一方, ヒトでは in vitro の半減期 (血中エステラー ゼによる代謝速度)および蛋白結合率に異性体間で差は なく，光学異性体変換も認められなかったことから， esmolol をヒトに投与したときの体内動態において光学 異性体間で差がないものと推察される．また，ラットに おける esmolol の心藏分布は受動拡散と考えられ，受動 拡散による膜の透過性には影著な種差はない10)ことか ら，ヒトにおける心臓への分布は $d$-esmolol と $l$-esmolol で差はないことが示唆される.

\section{要約}

Esmolol の ${ }^{14} \mathrm{C}$ 標識体をイ又およびラットにそれぞれ 
$10 \mathrm{mg} / \mathrm{kg}$ および $20 \mathrm{mg} / \mathrm{kg}$ の用量で単回静脈内投与し たときの血液中動態 (イヌ) と, 標的臓器である心臓中の 濃度推移(ラット)および血液中 ( in vitro) での代謝につ いて光学異性体間で比較し, またイヌおよびヒト血液中 での光学異性体変換について検討した，さらに，血清蛋 白結合率(ラット，イス，ヒト)について光学異性体間で 比較した.

1. イヌに ${ }^{14} \mathrm{C}$-esmolol を単回静脈内投与したときの 血液中濃度および AUC は $d$-esmolol の方が $l$-esmolol より 1.6 倍高く, 半減期は $d$-esmolol の方 $l$-esmolol よ り 1.7 倍長かった.

2. イヌおよびヒト血液に $d$-esmolol あるいは $l$-esmolol を添加し, $37^{\circ} \mathrm{C}$ でインキュベーションして測定し た半減期は, イスでは $d$-esmolol の方が $l$-esmolol より 1.4 倍長く, ヒトでは光学異性体間で差はみられなかっ た. また, イスの方がヒトより半減期は短かった.

3. ラットに ${ }^{14} \mathrm{C}$-esmolol を単回静脈内投与したとき の心蔵への分布量および濃度推移は光学異性体間で差は みられなかった。

4. イヌに ${ }^{14} \mathrm{C}-d$-esmolol あるいは ${ }^{14} \mathrm{C}-l$-esmolol を 単回静脈内投与したときの血液中には，それぞれの相対 する光学異性体は認められず，またイスおよびヒト血液 に $d$-esmolol あるいは $l$-esmolol を添加し, $37^{\circ} \mathrm{C}$ でイン キュベートしたときの血液中には，それぞれの相対する 光学異性体の生成はみられなかった.

5. ラット，イスおよびヒト血清における $d$-esmolol と $l$-esmolol の蛋白結合率に差は認められなかった．ま た，血清蛋白に対する結合率はヒト，イヌ，ラットの順 に高かった。

\section{文献}

1) Gorczynski R. J., Shaffer J. E. and Lee R. J.: Pharmacology of ASL-8052, a novel $\beta$-adrenergic receptor antagonist with an ultra-short duration of action. J. Cardiovasc. Pharmacol., 5: 668-677 (1983).

2) Zaroslinski J., Borgman R. J., O’Dennell J. P., Andrerson W. G., Erhardt P. W., Kams S. T., Reyn R. D., Lee R. J., Gorczynski R. J.: Ultra-short-acting beta-blockers: A proposal for the treatment of the critically ill patient. Life Sci., 31: 899-907 (1982).

3) Quon C. Y. and Stampfli H. F.: Biochemical properties of blood esmolol esterase. Drug Metab. Dispos., 13: 420-424 (1985).

4) Sum C. Y., Yacobi A., Kartzinel R., Stampfli H. F., Davis C. S. and Lai C. M.: Kinetics of esmolol, an ultra-short-acting beta blocker, and of its major metabolite. Clin. Pharmacol. Ther., 34: 427-434 (1983).

5) Reynolds R. D., Gorczynski R. J. and Quon C. Y.: Pharmacology and Pharmacokinetics of Esmolol. J. Clin. Pharmacol., 26(suppl): A3-A14 (1986).

6) Fan C.D., Zhao H. and Chow M. S. S.: Simple and rapid high-performance liquid chromatographic assay for esmolol. J. Chromatogr., 570(1): 217-223 (1991).

7) Quon C. Y., Mai K., Patil G. and Stampfli H. F.: Species differences in the stereoselective hydrolysis of esmolol by blood esterases. Drug Metab. Dispos., 16(3): 425-428 (1988).

8) 宮本好明, 村崎祐子, 岡村美弥子, 熊谷正道, 王鞍孝子, 河井祥一郎, 田村 隆, 高力 豊, 富澤宏樹 : Esmolol 9 ラットにおける体内動態, 薬物動態 16 (5)：415-426 (2001).

9）加藤隆一：臨床薬物動態学一臨床薬理学・薬物療法の基礎 として. 南江堂, 251-259 (1992).

10）杉山雄一：ファーマコキネティクス研究の方法と技術一前 臨床から臨床第 1 相へ一. 日本薬物動態学会, 127-130 (1993). 